\title{
A Tribute to Benedikte B. Scheiby:
}

\section{Introduction to the Tribute Video}

\author{
Seung-A Kim ${ }^{1}$ * \\ 1 Blended Learning Analytical Music Therapy Training Program, Molloy College, NY \\ *skim@molloy.edu
}

Published: 1 July 2019

I met Benedikte B. Scheiby at the World Congress of Music Therapy in Washington, D.C., in 1999, where she co-led the Analytical Music Therapy (AMT) workshop with colleague Dr. Inge Pedersen. From the moment I met her to the last supervision session with her in March 2018, I have been so grateful that she has been my visionary mentor. She provided such an inspiration, which grounded my passion for AMT. With her creativity, fluidity, and insightful approach to therapeutic work, she greatly influenced my perspective to the extent that I have framed my work through a culturally informed and analytical music therapy approach. Benedikte will always be an essential part of my personal and professional identity.

On behalf of MAR-AMTA (Past President: Dr. Michael Viega) and Dr. Kenneth Aigen, Benedikte's husband, Dr. Brian Harris, and I organized the memorial for the March 2019 MAR conference in Reston, VA, to come together to celebrate and remember the life and legacy of AMT pioneer Benedikte Scheiby. For this event, I have put together tribute videos and narratives from her former colleagues, friends, AMT practitioners, and trainees. Needless to say, there are many of us in and outside the US who have been touched greatly by her genuineness and wisdom. The only regret is that, due to time limitations, I was able to share merely a few of the many memories.

In this video, the program begins with the gratitude chant sung by two of Benedikte's last AMT trainees, Francesca Brennan and Meng Gu and ends with Benedikte's favorite Danish folk song, "Noget om en dejlig nat", which was sung by everyone who attended the conference. There is a musical reflection among the attendees, in addition to a series of narratives and video tributes which include AMT practitioners, Dr. Brian Abrams, Dr. Brain Harris, Audrey Morse, and also Juliane Kowski, one of Benedikte's first trainees, and Maria Gonsalves Schimpf, who engaged us all in a musical reflection. Also, fond memories of her were shared by long-term colleagues and friends Dr. David Ramsey who formerly worked with Benedikte at Beth Abraham Hospital, Professor Susan Feiner at NYU, and Dr. Kenneth Bruscia, Professor Emeritus of Music Therapy at Temple University. From outside the US, music tributes were expressed by Korean AMT trainees as well as by Dr. Inge Pedersen who established the Aarborg University Music Therapy program with Benedikte.

Arirang, which was sung by the Molloy College Korean AMT trainees, has a symbolic meaning that expresses a deep sorrow as well as strength and resilience. This largely symbolic song resonates strongly with my own sentiments and reflections of Benedik- 
te's impact over the years. As Dr. Bruscia shared, I will always remember Benedikte as "strong and resilient." Thank you, Benedikte.

\section{About the author}

Seung-A Kim, PhD, LCAT, MT-BC, Associate Professor, Director, Undergraduate Music Therapy, Coordinator, Blended Learning Analytical Music Therapy Training Program at Molloy College.

\section{Celebrating the Life and Legacy of Benedikte B. Scheiby}

https://youtu.be/inxOdzS6fCs

at MAR Conference, Reston, VA

Friday, March 8, 7:30PM-8:30PM

Remembering Benedikte Through Photos

\section{Welcome}

Analytical Music Therapists \& Analytical Music Therapy (AMT) Trainees

\section{Gratitude Chant}

Francesca Brennan, MA, LCAT, MT-BC \& Meng Gu, MA. Two of Benedikte's last AMT trainees. Blended Learning Analytical Music Therapy Training Program, Molloy College

\section{Musical Reflection}

Led by:

Juliane Kowski, MA, LCAT, MT-BC Analytical Music therapist, Owner of Music Connects in Berkeley, CA, Director of Child Care Solutions (ECMHP in Richmond)

Maria Gonsalves Schimpf, MA, MT-BC, Analytical Music Therapist at Denver Health hospital in Denver, Colorado

Legacy

An overview of Benedikte Scheiby's contributions to our field

Brian Abrams, PhD, MT-BC, LPC, LCAT, Analytical Music Therapist and Fellow of the Association for Music and Imagery, Associate Professor,Coordinator of Music Therapy at Montclair State University, NJ

\section{Reflections}

Brian Harris, PhD, MT-BC, LCAT Analytical Music Therapist, Adjunct Faculty Member at New York University and Private Practice in NYC

Audrey Morse, MA, MT-BC, LCAT, Analytical Music Therapist, Senior CAT at Mount Sinai West Hospital's Psychiatric Unit

AMT Trainees from Korea, Blended Learning AMT Training Program, Molloy College Seung-A Kim, PhD, LCAT, MT-BC, Analytical Music Therapist, Director, Undergraduate Music Therapy, Coordinator, Blended Learning AMT Training Program, Molloy College Kenneth Bruscia, PhD, Professor Emeritus of Music Therapy, Temple University Read by Amanda MacRae, MMT, MT-BC, Analytical Music Therapist, Doctoral Candidate, Temple University

Susan Feiner MA, MT-BC, LMSW, LCAT, Music Therapy Faculty, New York University David Ramsey, DA, LCAT, MT-BC.Former Assistant Director at Institute for Music and Neurologic Function. Former Adjunct Faculty, New York University Inge Nyggard Pedersen, PhD, Associate Professor, Aarborg University, Denmark

Dedication in Music: Danish Folk Song

Group Singing to commemorate Benedikte's life. Led by Seung-A Kim, PhD, LCAT, MTBC, Juliane Kowski, MA, LCAT, MT-BC, Analytical Music Therapists

Noget om en dejlig nat

Sфen ligger blank og våd.

B $\emptyset$ lgerne er stumme.

Kun en lille fiskerbåd 
kan man hфre brumme.

Tekst (Text author): Halfdan Rasmussen. Musik (Composer): Mogens Jermiin Nissen

This song is about a young woman laying under the white sail of a boat on a lake. The waves are dumb and only small hums from the fisherboat can be heard. The young woman is whistling and her soul is skating on the wet mirror of the lake. The skates are two small fishes, brilliant and shiny, and the night wind is ironing her bright mane (hair). Also starts are fluttering silently as moths around the lamp of the moon and the heart of the young woman is like a foal: Hear how it can stumble!!!!

Provided by Dr. Inge Nyggard Pedersen

Gong Ritual

SPECIAL THANKS:

- Dr. Kenneth Aigen for providing such beautiful and meaningful photos with us

- Benedikte's colleagues, friends, and AMT trainees who shared their beautiful tributes and photos

- Elizabeth Ingram, MT-BC, Molloy Graduate Assistant, for creating the memorial slide show.

- Dr. Michael Viega, MAR President and Conference Planning Committee for their support

- Benedikte's mentor, Mary Priestley, Benedikte's clients, and those who have passion for AMT

- A special thank you to Benedikte, for your creativity, openness, and vibrant passion for AMT practice

Wishing Papers \& Mingling

On a piece of paper, share a wish for Benedikte: a favorite memory, something that they would like to say to her or share with her in that moment. Then place it in the communal box. 